\title{
Micro- and macro-structure of cow, buffalo and mixed milk rasogolla: a comparative scanning electron and light microscope study
}

\author{
AK Adhikari, ON Mathur, GR Patil
}

National Dairy Research Institute, Division of Dairy Chemistry, Karnal 132 001, Haryana, India

(Received 15 October 1991; accepted 29 April 1992)

\begin{abstract}
Summary - Scanning electron and light-microscopic studies were carried out to provide information on the micro- and macro-structural differences between cow, buffalo and mixed milk rasogolla (a local Indian milk product obtained via acid coagulation followed by cooking in sugar syrup). Scanning electron microscopy of cow milk rasogolla revealed a loose, porous protein matrix with coalesced casein micelles forming a thread-like structure, while buffalo milk rasogolla had agglomerated casein micelles which were large and compact, and formed a scale- or layer-type structure. Casein micelles in mixed milk rasogolla formed a combination of thread- and scale-type structures. Fat globules collapsed and the membrane shrank noticeably in all the 3 samples. Larger fat globules were rost affected, while little or no effect was observed in small fat globules. Light microscopic investigation showed that cow milk rasogolla had smooth, small oval-shaped pores, whereas buffalo milk rasogolla had rough-edged, irregularly-shaped large pores. Mixed milk rasogolla had a heterogenous structure. The Instron and sensory textural examination agreed well with the composition and structural characteristics of rasogolla.
\end{abstract}

rasogolla / electron microscopy / light microscopy / heat treatment / texture / microstructure

Résumé - Microstructure et macrostructure de rasogolla de lait de vache, de lait de bufflesse et de lait de mélange. Des études au microscope électronique à balayage et au microscope optique ont été conduites pour déterminer les différences de micro- et macrostructure existant dans le rasogolla (produit laitier indien local obtenu par coagulation acide suivie d'une cuisson dans un sirop de sucre) obtenu à partir de lait de vache, de lait de bufflesse ou de mélange. La microscopie électronique à balayage du rasogolla de lait de vache révélait une matrice protéique lâche, poreuse, avec des micelles de caséine agglomérées en chaînettes filamenteuses. Au contraire, le rasogolla de lait de bufflesse présentait une structure compacte formée par de grosses micelles de caséine agglomérées en strates très denses. Le rasogolla de lait de mélange avait quant à lui une microstructure intermédiaire comportant à la fois des enchaînements micellaires stratifiés et filamenteux. Les globules gras avaient une présentation plus ou moins dégonflée selon leur taille, la membrane des plus gros étant la plus rétractée sur elle-même. L'examen au microscope optique révélait que le rasogolla au lait de vache avait 
des pores petits, aux contours lisses, de forme ovale tandis que le rasogolla au lait de buflesse présentait des pores gros, aux contours et formes irréguliers. Le rasogolla de lait de mélange avait une structure hétérogène. Les résultats de l'étude de la texture du rasogolla par l'Instron ou par analyse sensorielle étaient en accord avec les caractéristiques de composition et de structure.

rasogolla / microscopie électronique / microscopie optique / traitement thermique / texture / microstructure

\section{INTRODUCTION}

Ultrastructural studies have been used by food scientists for studying the topography and internal structure of a wide variety of food products since the early fifties. In recent years scanning electron microscopy (SEM) has gained considerable importance in the study of surface topology and to develop correlations between the structure and the physical appearance of various food materials. It offers rapid and simple specimen preparation, and provides great depth of focus, producing pictures with a 3-dimensional impression, an excellent tool in the study of gel structure (Kalab and Harwalkar, 1973).

Rasogolla, an Indian sweetened milk product, is manufactured by cooking chana (an acid-coagulated soft cottage cheese analogue) in a concentrated sugar syrup to a soft, spongy consistency. Among the Indian dairy products it has a significant market value due to its extreme popularity throughout India and abroad. The preparation of a standard quality product is still carried out by sweetmeat makers. Research had only been carried out on its production technology, some process modifications and its shelf-life (Date et al, 1958; Jagtiani et al, 1960; Bhattacharya and Des Raj, 1980; Soni et al, 1980 ) but an in-depth study has not yet been performed.

The objective of this study was to manufacture good quality cow, buffalo and mixed milk rasogolla comparable to the best market samples and to study their micro- and macro-structure, texture and composition in order to obtain an insight into the possible interrelationships among these parameters.

\section{MATERIALS AND METHODS}

The manufacture of cow, buffalo and mixed milk rasogollas was carried out as depicted in the flow diagram in figure 1. Rasogolla samples were analysed after $12 \mathrm{~h}$ of soaking in $40 \%$ sugar syrup.

\section{Analytical methods}

The rasogolla samples were kept on a wire gauge (200-mesh size) for $2 \mathrm{~h}$ for complete drainage of the loosely bound sugar syrup and thoroughly homogenized using mortar and pestle before making the chemical analyses.

Moisture content was determined by the vacuum-drying procedure (AOAC, 1975), fat by the Mojonnier and Tory (1925), protein by the Kjeldahl (AOAC, 1975) and lactose and sucrose by the Birch and Mwangelwa method (1974). Ash content was determined according to the AOAC (1984) and calcium by the Davies and White method (1962).

\section{Objective textural analysis}

Textural properties such as hardness, cohesiveness, springiness, gumminess and chewiness were determined by an Instron universal testing machine (Model 4301), equipped with a 10-N load cell. Cylindrical samples $1.5 \mathrm{~cm}$ in height 


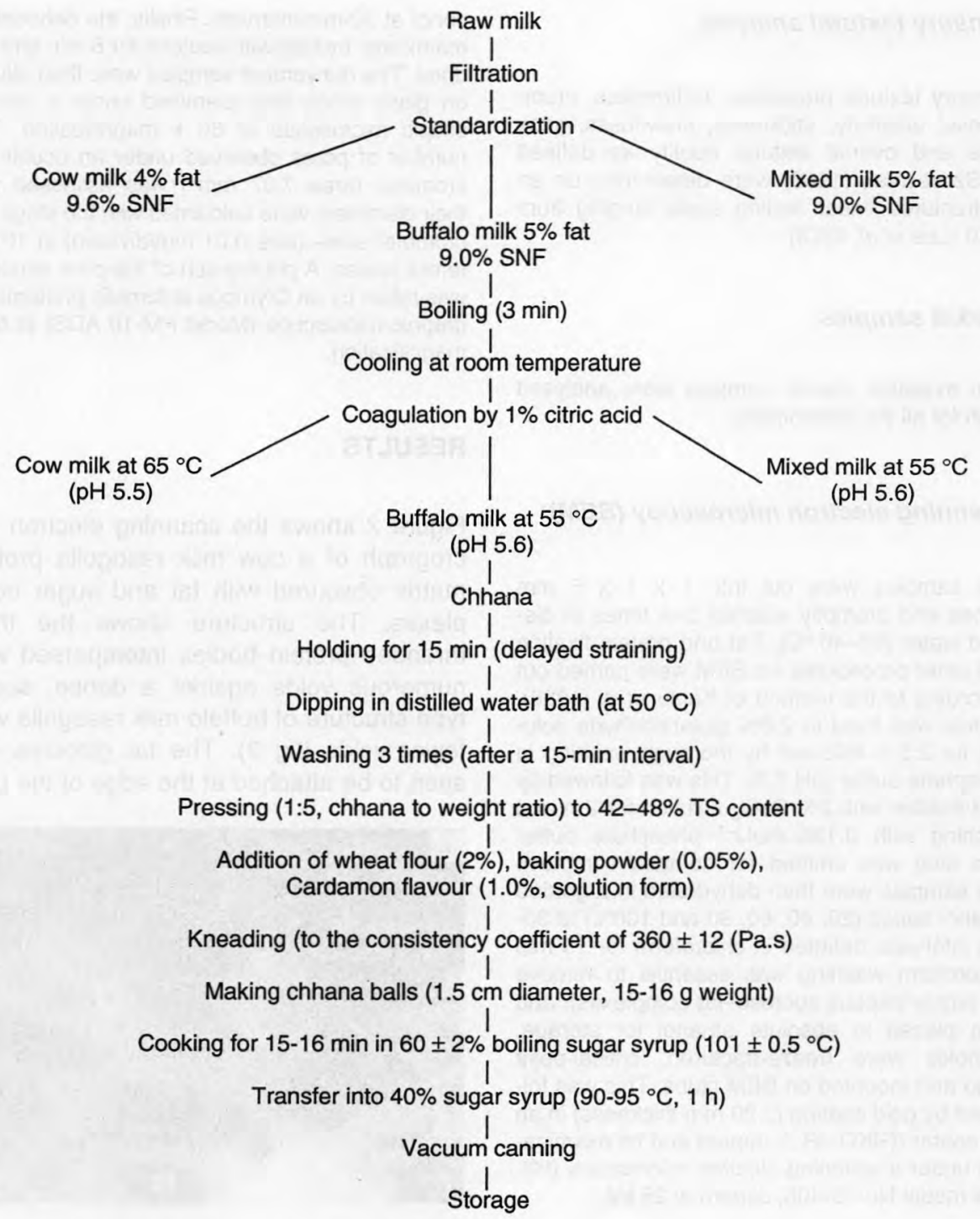

Fig 1. Flow diagram for the manufacture of cow, buffalo and mixed milk rasogolla. Diagramme de fabrication du rasogolla.

and $1.9 \mathrm{~cm}$ in diameter were compressed to $26.70 \%$ of their original height at a cross-head speed of $250 \mathrm{~mm} \cdot \mathrm{min}^{-1}$. The results were meas- ured from the force deformation curves according to Brady et al (1985) and expressed on a per unit cross-sectional basis (ie per $\mathrm{mm}^{2}$ ). 


\section{Sensory textural analysis}

Sensory textural properties, ie firmness, crumbliness, elasticity, stickiness, chewiness, juiciness and overall textural quality as defined by Szczesniak (1963) were determined on an unstructured linear testing scale ranging from 1-10 (Lee et al, 1978).

\section{Market samples}

Best available market samples were analysed fresh for all the parameters.

\section{Scanning electron microscopy (SEM)}

The samples were cut into $1 \times 1 \times 5 \mathrm{~mm}$ pieces and promptly washed 3-4 times in distilled water $\left(37-40^{\circ} \mathrm{C}\right)$. Fat and protein fixation and other procedures for SEM were carried out according to the method of Kalab et al (1988). Protein was fixed in $2.8 \%$ glutaraldehyde solution for $2.5 \mathrm{~h}$ followed by thorough washing in phosphate buffer $(\mathrm{pH} 7.3)$. This was followed by post-fixation with $2 \% \mathrm{OsO}_{4}$ solution for $2 \mathrm{~h}$ and washing with $0.135 \mathrm{~mol}^{-1} \mathrm{I}^{-1}$ phosphate buffer (this step was omitted for defatted samples). The samples were then dehydrated in a graded ethanol series $(20,40,60,80$ and $100 \%)$ at 30 min intervals, defatted in chloroform for $15 \mathrm{~min}$ (chloroform washing was essential to remove the highly viscous sucrose-fat complexes), and then placed in absolute ethanol for storage. Samples were freeze-fractured, critical-point dried and mounted on SEM stubs. This was followed by gold coating ( $220 \mathrm{~mm}$ thickness) in an ion coater (GIKO -IB-3, Japan) and by examination under a scanning electron microscope (Hitachi model No -S-405, Japan) at $25 \mathrm{kV}$.

\section{Light microscopic study}

The size and number of pore distribution in the rasogolla matrix were determined under a stereoscopic compound microscope. Very thin sections of rasogolla samples $(0.1 \mathrm{~mm}$ thick, $10 \mathrm{~mm}$ wide) were obtained and washed carefully in warm distilled water $\left(40^{\circ} \mathrm{C}\right)$. This was followed by washing with an ethanol series (20-100\% conc) at 30-min intervals. Finally, the dehydrated matrix was treated with acetone for $5 \mathrm{~min}$ and airdried. The dehydrated samples were then placed on glass slides and examined under a stereoscopic microscope at $60 \times$ magnification. The number of pores observed under an ocular micrometer (area $7.07 \mathrm{~mm}^{2}$ ) was assessed and their diameters were calculated with the stage micrometer scale (size $0.01 \mathrm{~mm} /$ division) in 10 different places. A photograph of the pore structure was taken by an Olympus automatic photomicrographic microscope (Model PM-10 ADS) at $50 \times$ magnification.

\section{RESULTS}

Figure 2 shows the scanning electron micrograph of a cow milk rasogolla protein matrix obscured with fat and sugar complexes. The structure shows the thick threaded protein bodies interspersed with numerous voids against a dense, scaletype structure of buffalo milk rasogolla with fewer voids (fig 3 ). The fat globules are seen to be attached at the edge of the pro-

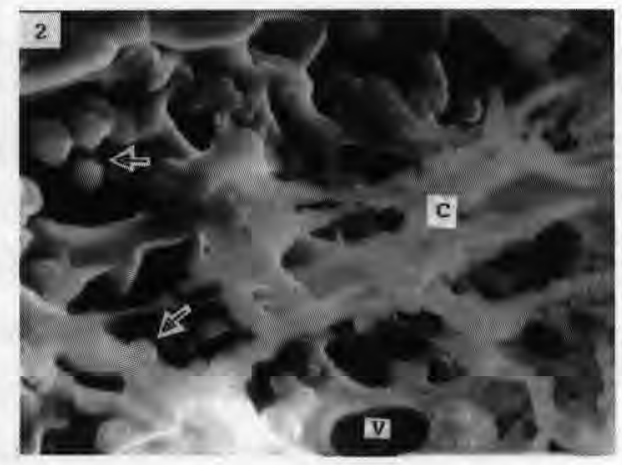

Fig 2. Scanning electron micrograph of cow milk rasogolla (bar $20 \mu \mathrm{m})$. Threaded, agglomerated casein micelles (C) interspersed with numerous voids (V) and fat globules (arrow) attached at the edge of the coalesced micelles.

Micrographie MEB de rasogolla de lait de vache (barre $20 \mu \mathrm{m}$ ) montrant une agglomération filamenteuse des micelles de caséine (C), avec de nombreux vides (V) et les globules gras (flèches) attachés sur le bord des micelles coalescentes. 


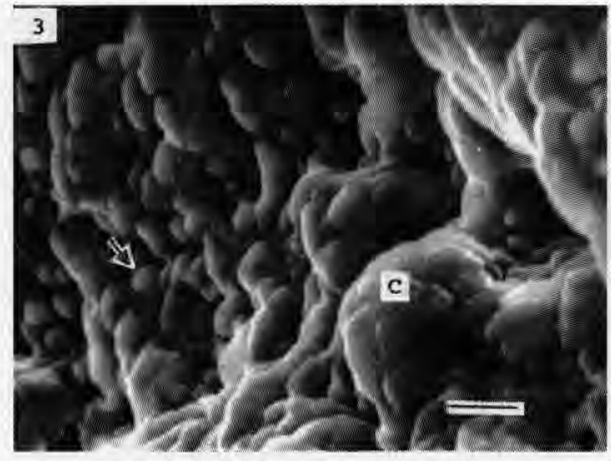

Fig 3. Scanning electron micrograph of buffalo milk rasogolla (bar $20 \mu \mathrm{m}$ ) showing dense, scale-type agglomerated casein micelles (C) interspersed with fat globules (arrow). The obscured surface was mainly due to fat and protein complexes produced during cooking.

Micrographie MEB de rasogolla de lait de bufflesse (barre $20 \mu \mathrm{m}$ ) montrant une agglomération dense de type stratifié des micelles de caséine (C) entremêlées avec les globules gras (flèche). La surface obscure provenait principalement des complexes matière grasse/protéine produits pendant la cuisson.

tein matrix and are fuzzy in appearance (arrow). In the case of mixed milk rasogolla (fig 4) the structure revealed a ragged protein matrix with threaded as well as scaletype agglomerated casein micelles fused densely together with numerous small voids.

As illustrated in figure 5 , the scanning electron micrograph of cow milk rasogolla showed a fat globule attached to the coalesced-threaded casein micelles. Large fat globules (diam $\geq 10 \mu \mathrm{m}$ ) collapsed and looked like empty balloons while the small fat globules $(\leq 10 \mu \mathrm{m})$ remained unaffected (arrow). In the case of buffalo milk rasogolla (fig 6), the same effect was observed in the fat globules, but the membrane had shrunk and wrinkled to a greater extent than the cow milk rasogolla fat globule. The fat globule was found entrapped about

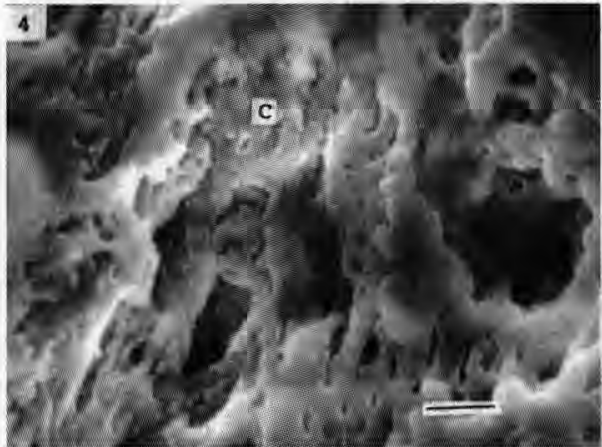

Fig 4. Scanning electron micrograph of a mixed milk rasogolla (bar $20 \mu \mathrm{m}$ ) showing threaded and scale-type coalesced casein micelles (C) admixed together.

Micrographie MEB de rasogolla de lait de mélange (barre $20 \mu \mathrm{m}$ ) montrant une agglomération à la fois filamenteuse et stratifiée des micelles de caséine (C).

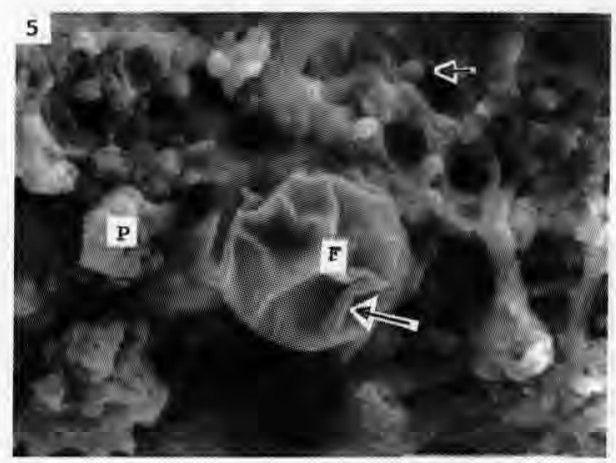

Fig 5. Scanning electron micrograph of a cow milk rasogolla fat globule (bar $5 \mu \mathrm{m}$ ). Collapsed fat globule $(F)$ and shrunken membrane (large arrow), attached at the edge of the protein matrix $(P)$. Small fat globules (small arrow) were least affected.

Micrographie MEB de globule gras de rasogolla de lait de vache (barre $5 \mu \mathrm{m}$ ). Globule gras (F) dégonflé et à membrane rétractée (grande flèche) attachée au bord de la matrice de protéine (P). Petit globule gras (petite flèche) peu affecté. 


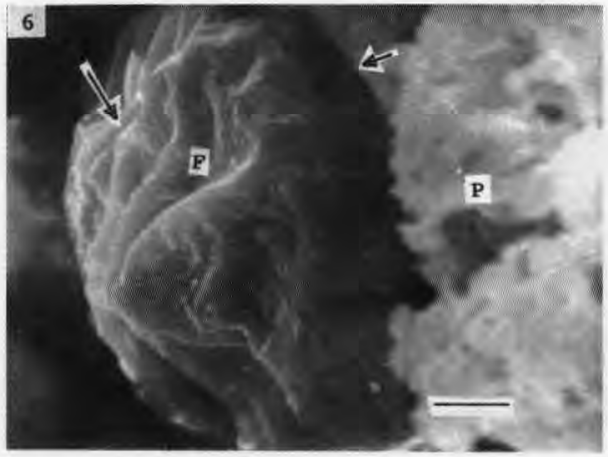

Fig 6. Scanning electron micrograph of buffalo milk rasogolla fat globule (bar $5 \mu \mathrm{m}$ ). Fat globule $(F)$ was embedded about half of its original size at the edge of the protein matrix $(P)$ (obscured with fat and sugar syrup) and membrane wrinkled severely (large arrow). Fat globule partially detached from the matrix (small arrow).

Micrographie MEB de globule gras de rasogolla de lait de bufflesse (barre $5 \mu \mathrm{m}$ ). Globule gras (F) enfoncé à environ la moitié de sa taille d'origine dans les micelles de caséine agglomérées $(P)$ sur le bord de la matrice (obscurcie à cause de la matière grasse et du sirop de sucre) et présentant une membrane plissée de façon importante (grande flèche). Globule gras partiellement détaché de la matrice (petite flèche).

$50 \%$ of its original size at the edge of the agglomerated protein bodies, partially ruptured and detached from the matrix (arrow). In the case of mixed milk rasogolla, the fat globules (fig 7) collapsed and ruptured to a greater extent compared to cow and buffalo milk rasogolla, while no effect was noticed in small fat globules (arrow) which were entrapped in the coalesced protein bodies. Study of the defatted casein matrix of cow milk rasogolla (fig 8) revealed loose, agglomerated protein particles with no single casein micelle present. The gritty casein micelles were folded together, forming a loose, porous matrix with irregularly shaped voids which indicate the air space or the space which had initially

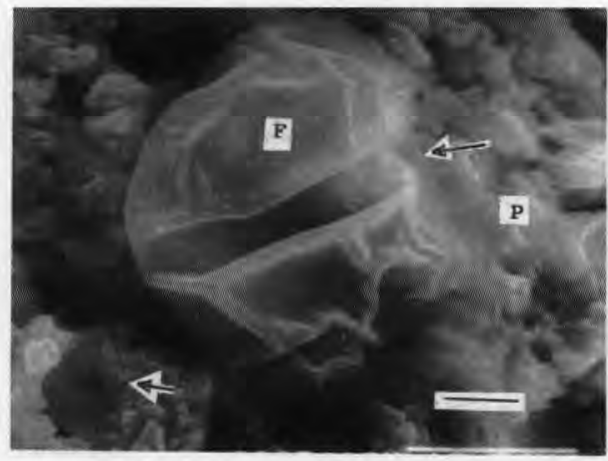

Fig 7. Scanning electron micrograph of mixed milk rasogolla fat globule (bar $5 \mu \mathrm{m}$ ). Large collapsed fat globule $(F)$, partially ruptured (large arrow), was embedded in the protein matrix $(P)$. No effect was noticed in the small fat globule (small arrow).

Micrographie MEB de globule gras de rasogolla de lait de mélange (barre $5 \mu \mathrm{m}$ ). Gros globule gras (F) dégonflé et partiellement rompu (grande flèche) enfoncé dans la matrice de protéine $(P)$ alors qu'aucun effet n'est visible sur les petits globules gras (petite flèche).

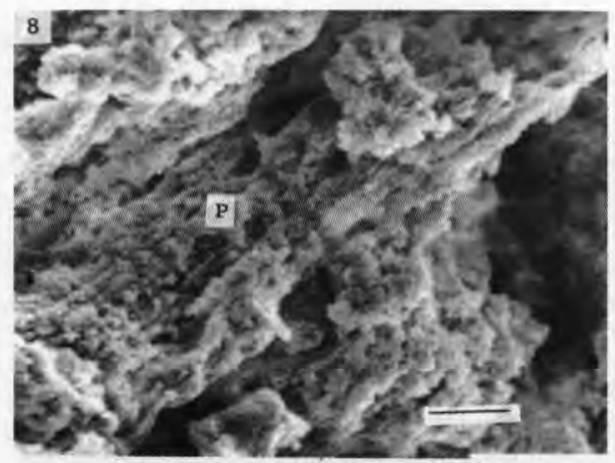

Fig 8. Scanning electron micrograph of a defatted casein matrix of cow milk rasogolla (bar 50 $\mu \mathrm{m})$. Agglomerated, loosely bound, gritty protein particles $(P)$ with no single casein subunits.

Micrographie MEB de la matrice de caséine dégraissée de rasogolla de lait de vache (barre 50 $\mu \mathrm{m})$. Agglomération de particules de protéine (P) sableuse, liée de façon lâche, ne laissant pas apparaître d'entité de sous-unité caséinique. 


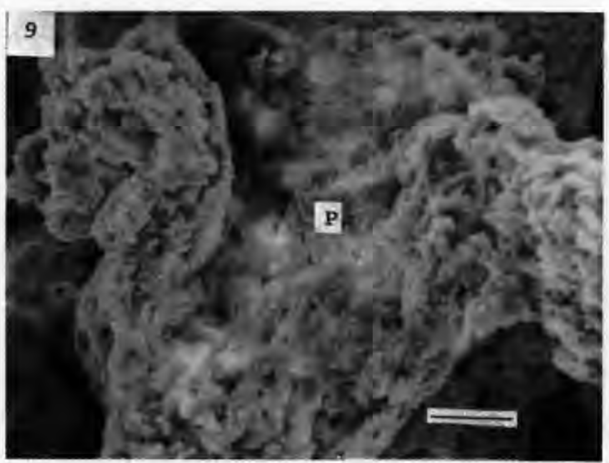

Fig 9. Scanning electron micrograph of a defatted casein matrix of buffalo milk rasogolla (bar $50 \mu \mathrm{m})$. The casein micelles $(P)$ coalesced more densely, forming a more compact body than the cow milk rasogolla matrix.

Micrographie MEB de la matrice de caséine dégraissée de rasogolla de lait de bufflesse (barre $50 \mu \mathrm{m})$. Micelles de caséine $(P)$ assemblées de façon plus dense et formant une pâte plus compacte que la matrice du rasogolla du lait de vache.

been filled with sugar syrup before sample preparation.

Figure 9 shows the defatted protein matrix of buffalo milk rasogolla with more compact, uneven and large clumps of casein micelles with fewer voids. Whereas the defatted protein matrix of mixed milk rasogolla (fig 10) showed a more ragged surface with threaded, loose protein particles interlinked to the densely-fused large agglomerates of casein micelles.

Figure 11 shows the scanning electron micrograph of a defatted market rasogolla sample having similar threaded and folded protein bodies with numerous large voids, resembling the laboratory-manufactured cow milk rasogolla.

At higher magnification the defatted protein matrix of cow, buffalo and mixed milk rasogolla (figs 12-14) confirm the above observations. The cow milk rasogolla matrix (fig 12) revealed a loose, threaded

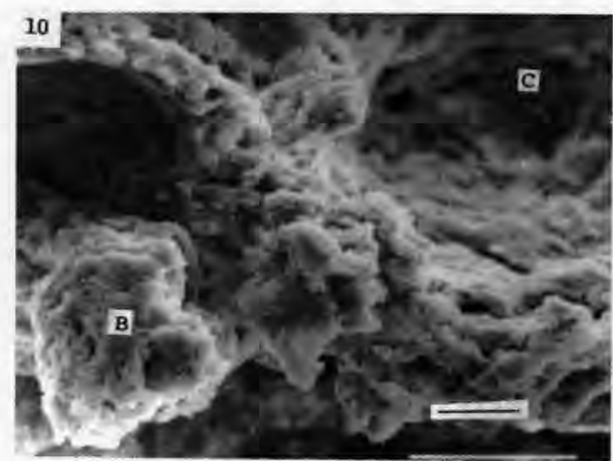

Fig 10. Scanning electron micrograph of a defatted casein matrix of mixed milk rasogolla (bar 50 $\mu \mathrm{m}$ ) showing the heterogeneous structure of the matrix having both loosely bound threaded casein micelles (C) and compact large casein micelles $(B)$ joined abruptly to form a more ragged and uneven protein matrix.

Micrographie MEB de la matrice de caséine dégraissée de ragosolla de lait de mélange (barre $50 \mu \mathrm{m}$ ) montrant la structure hétérogène de la matrice avec à la fois des micelles de caséine filamenteuses, liées de façon lâche (C) et des micelles de caséine compactes et grosses (B), assemblées irrégulièrement pour former une matrice de protéine plus désordonnée et inégale.

structure with numerous small voids. Thick thread-like micelles are arranged in a regular and folded manner, whereas buffalo milk rasogolla matrix (fig 13) showed large agglomerated clumps of casein micelles fused densely together, forming a layer- or scale-type structure. The matrix is more compact and uneven, with fewer voids than cow milk rasogolla. In the case of mixed milk rasogolla (fig 14), the structure showed a combination of thread- and scale-type structure.

One of the best available market samples studied in this context largely resembled the cow milk rasogolla structure (fig 15) having small, gritty casein micelles joined loosely together and with a threaded appearance. The irregular-shaped voids 


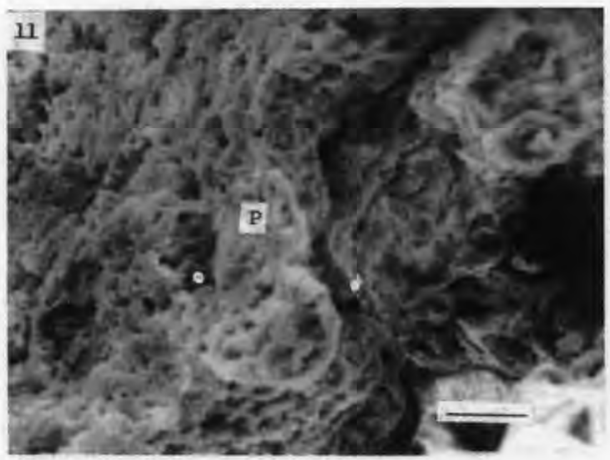

Fig 11. Scanning electron micrograph of the defatted protein matrix of a market rasogolla sample (bar $50 \mu \mathrm{m}$ ). The coalesced threaded protein particles $(P)$ closely resemble the structure of laboratory manufactured cow milk rasogolla.

Micrographie MEB de la matrice de protéine dégraissée d'un échantillon de rasogolla du commerce (barre $50 \mu \mathrm{m}$ ). Particules de protéines assemblées sous forme filamenteuse $(P)$ ressemblant à la structure du rasogolla de lait de vache fabriqué au laboratoire.

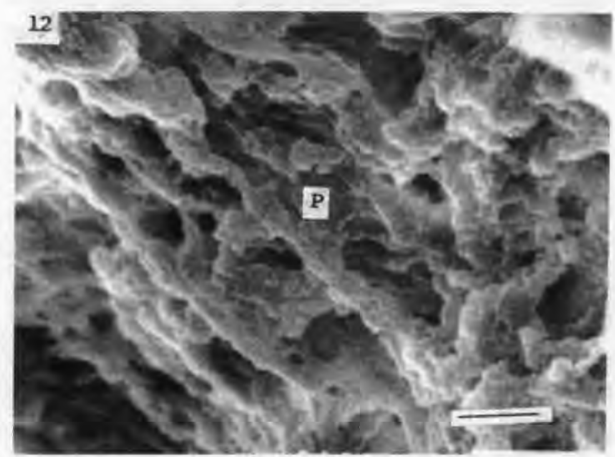

Fig 12. Scanning electron micrograph of the defatted protein matrix of cow milk rasogolla (bar $15 \mu \mathrm{m})$. At higher magnification the structure revealed thick threaded protein particles $(P)$ joined together by some bridging material interspersed with numerous large voids.

Micrographie MEB de la matrice de protéine dégraissée de rasogolla de lait de vache (barre 15 $\mu \mathrm{m})$. $\dot{A}$ un grandissement supérieur, la structure révèle des particules de protéine épaisses sous forme filamenteuse $(P)$, reliées par quelques ponts et comportant de nombreux gros vides.

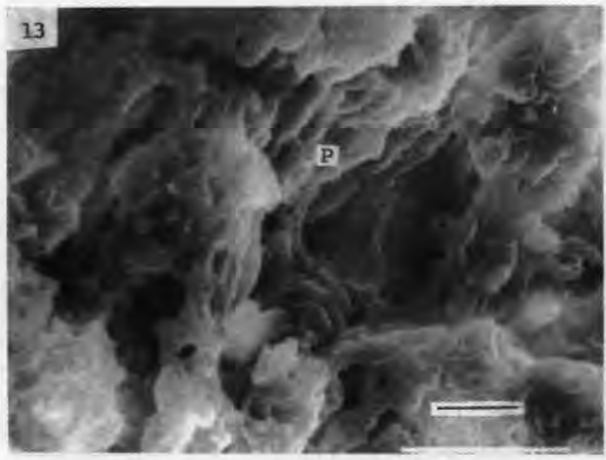

Fig 13. Scanning electron micrograph of buffalo milk rasogolla protein matrix (P) (bar $15 \mu \mathrm{m})$. At higher magnification it exhibited a more compact and ragged surface having scale or layertype structure and fewer voids than that of cow milk rasogolla.

Micrographie MEB de la matrice de protéine $(P)$ de rasogolla de lait de bufflesse (barre $15 \mu \mathrm{m}$ ). A un grandissement supérieur, elle révèle une surface plus compacte et désordonnée que celle du rasogolla du lait de vache et présente une structure de type stratifié avec moins de vides.

might have been filled with air or sugar syrup and the round-shaped remnants might have been filled with fat globules before their extraction during the preparation of the sample for SEM study.

The light microscopic study of a crosssection of each of the 3 types of rasogolla matrix was carried out to determine the structural differences in size, shape and number of pores per unit area, which are supposed to largely influence their textural characteristics.

Cow milk rasogolla matrix (fig 16) showed numerous small, smooth-edged and oval-shaped pores uniformly distributed, whereas buffalo milk rasogolla matrix (fig 17) showed large, irregularly shaped, pores with corrugated edges, unevenly distributed throughout the matrix. On the other hand, the mixed milk product (fig 18) showed both small and large pores with a 


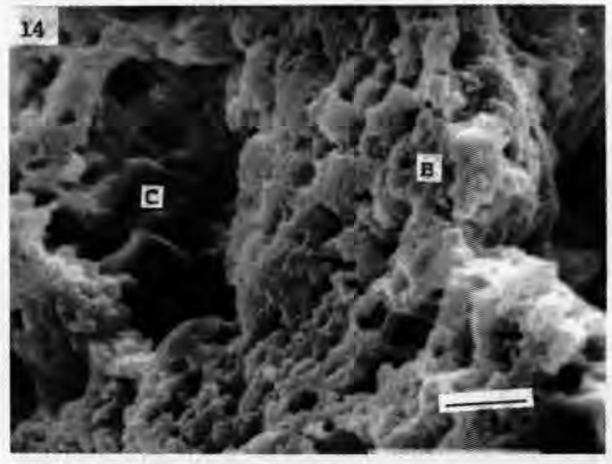

Fig 14. Scanning electron micrograph of a defatted protein matrix of mixed milk rasogolla at higher magnification (bar $15 \mu \mathrm{m}$ ). The structure revealed the combination of loose, thread-like protein particles (C) and compact, large scaletype protein agglomerates (B) fused loosely together.

Micrographie MEB de la matrice de protéine dégraissée de rasogolla de lait de mélange à un grandissement supérieur (barre $15 \mu \mathrm{m}$ ). La structure révèle la combinaison de particules de protéine lâches sous forme filamenteuse (C) et une structure compacte, de type stratifié (B).

smooth and a rough-edged surface interspersed. The number of pores counted per $7.07 \mathrm{~mm}^{2}$ amounted to 25-30 (av 30), 2228 (av 25) and 23-28 (av 28) for cow, buffalo and mixed milk rasogolla respectively. The average diameter of these pores was $0.90 \mathrm{~mm}, 1.60 \mathrm{~mm}$ and $1.50 \mathrm{~mm}$ for cow, buffalo and mixed milk rasogolla (table I), respectively.

The average chemical composition of cow milk rasogolla (table II) showed higher moisture and sucrose contents but lower fat, protein, lactose, ash and calcium contents than that in buffalo milk rasogolla. Mixed milk rasogolla had slightly higher levels of fat, protein, lactose, ash and calcium but lower moisture and sucrose contents than that of the cow milk product. Market samples had closer compositional makeup to that of cow milk rasogolla manufactured in the laboratory.

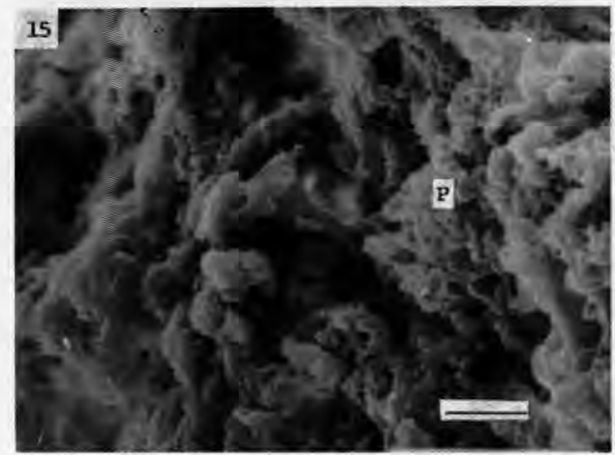

Fig 15. Scanning electron micrograph of market rasogolla sample at higher magnification (bar 15 $\mu \mathrm{m})$. The structure shows the gritty, loosely bound threaded protein particles $(P)$ with no evidence of single casein micelles, resembling the laboratory manufactured cow milk rasogolla.

Micrographie MEB d'un échantillon de rasogolla du marché à un grandissement supérieur (barre $15 \mu \mathrm{m})$. La structure manifeste des particules de protéine peu liées, d'aspect sableaux $(P)$ sans observation de micelle de caséine isolée, et ressemblant beaucoup à celle du rasogolla de lait de vache fabriqué au laboratoire.

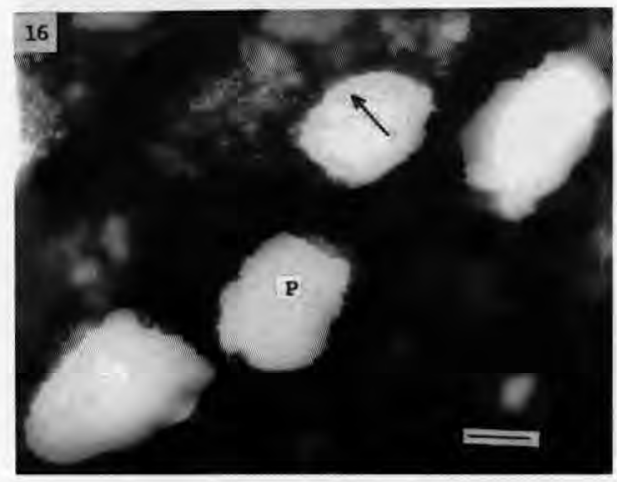

Fig 16. Light microscopic micrograph $(50 \mathrm{x})$ of cow milk rasogolla matrix (bar $350 \mu \mathrm{m}$ ). Pores are small $(P)$, oval-shaped and smooth-edged (arrow) and are uniformly distributed throughout the matrix.

Micrographie optique (50x) de la matrice de rasogolla de lait de vache (barre $350 \mu \mathrm{m}$ ). Les pores sont petits $(P)$, de forme ovale et aux rebords lisses (flèche), et distribués uniformément dans la matrice. 


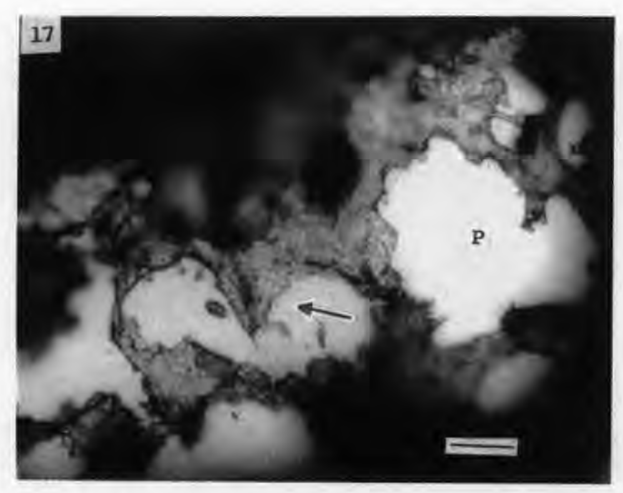

Fig 17. Light microscopic micrograph $(50 \mathrm{x})$ of buffalo milk rasogolla matrix (bar $350 \mu \mathrm{m}$ ). Pores are large $(P)$, irregularly shaped, corrugated at the edges (arrow), and are unevenly distributed throughout the matrix.

Micrographie optique (50x) de la matrice de rasogolla de lait de bufflesse (barre $350 \mu \mathrm{m}$ ). Les pores sont gros $(P)$, de forme irrégulière, aux rebords irréguliers (flèche) et distribués inégalement dans la matrice.

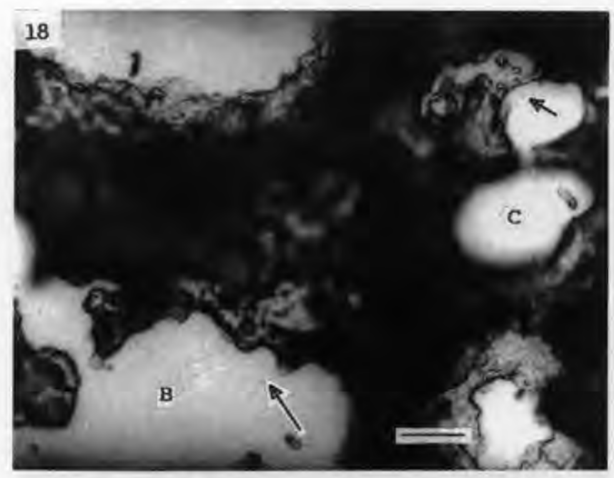

Fig 18. Light microscopic micrograph (50x) of mixed milk rasogolla matrix (bar $350 \mu \mathrm{m}$ ). The structure shows both large, rough-edged (B) and small, smooth-edged (C) pores interspersed throughout.

Micrographie optique (50x) de la matrice de rasogolla de lait de mélange (barre $350 \mu \mathrm{m}$ ). La structure révèle à la fois des pores gros et aux rebords irréguliers $(B)$ et des pores petits, aux rebords lisses $(C)$, entremêlés.
Table III shows the textural values of cow, buffalo and mixed milk rasogolla as obtained by the Instron. It can be seen from the table that buffalo milk rasogolla was almost twice as hard as cow milk rasogolla, but mixed milk rasogolla was slightly harder than the cow milk product. The values for cohesiveness of these 3 products were almost similar, but buffalo milk rasogolla had maximum springiness $(6.20 \mathrm{~mm})$, and was springier than cow and mixed milk rasogolla (4.8 and $4.2 \mathrm{~mm}$ respectively). Gumminess and chewiness of buffalo milk rasogolla had significantly higher values (almost double) than those of cow or mixed milk rasogolla. The market rasogolla sample had closer textural values to that of cow milk rasogolla. No adhesive force was recorded for rasogolla by the Instron.

Sensory textural scores of laboratory and market manufactured rasogollas (table IV) show that cow milk rasogolla had lower firmness, elasticity and chewiness but higher crumbliness, stickiness, juiciness and better overall textural quality than that of buffalo milk rasogolla, whereas market samples had closer sensory textural scores to that of cow milk rasogolla, followed by mixed milk rasogolla.

\section{DISCUSSION}

The structure formation of acid and heat coagulated milk gels is influenced by several factors such as the $\mathrm{pH}$, heat, salt system, culture and thickening agents (Heertje et al, 1985). The casein micelles, a macromolecular assembly of $\alpha-, \beta$ - and $\kappa$ caseins, are held together by an amorphous calcium-phosphate-citrate complex and occur as a separate entity in milk. The ultrastructure fully develops in acidcoagulated milk gels, only if the milk had been heated to $90^{\circ} \mathrm{C}$, which results in the formation of $\kappa$-casein and $\beta$-lactoglobulin complexes (Zittle et al, 1962). 
Table I. Distribution of pores and their sizes of cow, buffalo and mixed milk rasogolla matrix as examined by light microscope.

Distribution et taille de pores de la matrice de rasogolla de lait de vache, de bufflesse et de lait de mélange examinées au microscope optique.

\begin{tabular}{lcccc}
\hline Particulars & Cow & Buffalo & Mixed & Market \\
\hline $\begin{array}{l}\text { No of pores } \\
\left.\text { (per 7.07 } \mathrm{m}^{2}\right)\end{array}$ & $\begin{array}{c}25-35 \\
(\text { av } 30)\end{array}$ & $\begin{array}{c}22-28 \\
(\text { av 25) }\end{array}$ & $\begin{array}{c}23-28 \\
(\text { av 28) }\end{array}$ & $\begin{array}{c}26-36 \\
\text { (av 32) }\end{array}$ \\
$\begin{array}{l}\text { Diameter of } \\
\text { pores }(\mathrm{mm})\end{array}$ & $\begin{array}{l}0.80-1.10 \\
(\text { av } 0.90)\end{array}$ & $\begin{array}{l}0.90-1.90 \\
(\text { av 1.60) }\end{array}$ & $\begin{array}{l}0.80-1.80 \\
(\text { av 1.50) }\end{array}$ & $\begin{array}{l}0.70-1.25 \\
\text { (av 1.05) }\end{array}$ \\
\hline
\end{tabular}

Av: average.

Upon acidification of milk, micelle-bound calcium phosphates get solubilized and the casein-whey protein complexes become agglomerated by charge neutralization resulting in the formation of a network of chains and clusters (Heertje et al, 1985). Micellar disintegration takes place at a lower $\mathrm{pH}$, resulting in conglomerated casein micelles with fat and whey proteins entrapped in them. These phenomena are advocated in chhana making, which on further cooking in concentrated sugar syrup was transformed into a typical, ragged, spongy and porous consistency, ie to that of rasogolla.

The compact, granular casein matrix of chhana altered markedly during cooking in $60 \%$ sugar syrup to form a fluffy, porous, thread- or scale-like folded structure in rasogolla. The strong interlinkages of the coalesced protein particles were severely damaged during cooking and the compactness gradually disappeared to produce a ragged, uneven, loose protein matrix with

Table II. Average chemical compositon* of cow, buffalo and mixed milk rasogolla. Composition chimique moyenne du rasogolla.

\begin{tabular}{lrrrr}
\hline Constituents (\%) & Cow & \multicolumn{1}{c}{ Buffalo } & Mixed & Market \\
\hline Moisture & $48.50(1.40)$ & $43.25(1.65)$ & $45.60(1.30)$ & $47.80(1.70)$ \\
Fat & $6.82(0.66)$ & $8.60(1.05)$ & $7.55(0.85)$ & $6.35(0.75)$ \\
Protein & $10.30(0.95)$ & $14.86(1.06)$ & $12.64(1.16)$ & $9.75(1.25)$ \\
Lactose & $0.50(0.20)$ & $0.78(0.35)$ & $0.86(0.40)$ & $0.62(0.30)$ \\
Ash & $0.68(0.08)$ & $0.95(0.10)$ & $0.82(0.06)$ & $0.76(0.12)$ \\
Sucrose & $33.20(1.80)$ & $31.56(1.50)$ & $32.53(1.64)$ & $34.72(2.10)$ \\
Calcium & $0.24(0.04)$ & $0.38(0.08)$ & $0.29(0.06)$ & $0.26(0.07)$ \\
& & & & \\
\hline
\end{tabular}

- Average of 3 replicates. Figures in parentheses indicate standard deviations. 
Table III. Textural values ${ }^{*}$ of cow, buffalo and mixed milk rasogolla as obtained by the Instron universal testing machine.

Caractéristiques texturales du rasogolla obtenues à I'Instron.

\begin{tabular}{lrrrr}
\hline Textural attributes & Cow & Buffalo & Mixed & Market \\
\hline Hardness (mN) & $10.01(1.35)$ & $18.31(2.10)$ & $13.21(1.85)$ & $11.20(1.65)$ \\
Cohesiveness & $0.59(0.08)$ & $0.65(0.06)$ & $0.62(0.05)$ & $0.58(0.06)$ \\
Springiness $(\mathrm{mm})$ & $4.80(0.35)$ & $6.20(0.65)$ & $4.20(0.50)$ & $4.90(0.40)$ \\
Guminess $(\mathrm{mN})$ & $5.90(1.35)$ & $11.90(1.70)$ & $8.20(1.40)$ & $6.50(1.30)$ \\
Chewiness $(\mathrm{mN} . \mathrm{mm})$ & $28.70(2.45)$ & $73.70(3.75)$ & $34.50(3.60)$ & $31.85(3.55)$ \\
& & & & \\
\hline
\end{tabular}

- Average of 6 replicates. Figures in parentheses indicate standard deviations.

the development of numerous large and small voids throughout the matrix. The fat phase became highly vulnerable and the membrane convoluted, resulting in its shrinkage and rupture, liberating free fat. This presumably was because of longer and rigorous heating $\left(\geq 100^{\circ} \mathrm{C}\right)$ in concentrated sugar syrup which produced a high osmotic pressure difference surrounding the fat globule membrane leading to the collapse or rupture of the membrane. Cow milk, which contains somewhat smaller fat globules than those in buffalo milk (Ganguli, 1974) was less affected, whereas the large fat globules $(\geq 10 \mu \mathrm{m})$ in buffalo or mixed milk rasogolla became more prone to such heating and their globular smooth surfaces became severely shrunken.

Creamer et al (1978) observed a folded, thread-like structure in casein micelles heated to $100{ }^{\circ} \mathrm{C}$, similar to that in cow milk rasogolla. However, Kalab et al (1988) observed that frying of cow milk paneer (another chhana-like Indian style cottage cheese) in oil severely altered the granularity of the protein matrix while it disappeared completely in buffalo milk paneer. They also noted that the fat globule cluster altered during frying and acquired sharp and pointed outlines as compared to their

Table IV. Average* sensory textural score of rasogolla on unstructured linear rating scale (1-10).

Caractéristiques texturales du rasogolla obtenues par analyse factorielle (échelle de notation de 1 à 10 ).

\begin{tabular}{lcccc}
\hline Sensory textural attributes & Cow & Buffalo & Mixed & Market \\
\hline Firmness & $5.45(0.55)$ & $8.10(0.75)$ & $7.50(0.60)$ & $5.60(0.65)$ \\
Crumbliness & $2.60(0.35)$ & $2.10(0.40)$ & $4.00(0.85)$ & $2.45(0.45)$ \\
Elasticity & $7.30(0.50)$ & $8.80(0.60)$ & $8.10(0.35)$ & $7.50(0.40)$ \\
Stickiness & $2.45(0.25)$ & $1.50(0.15)$ & $2.05(0.20)$ & $2.30(0.30)$ \\
Chewiness & $6.85(0.50)$ & $8.45(0.55)$ & $7.40(0.65)$ & $7.05(0.70)$ \\
Juiciness & $9.10(0.45)$ & $6.60(0.50)$ & $7.50(0.40)$ & $9.20(0.50)$ \\
Overall textural quality & $8.40(0.50)$ & $6.80(0.45)$ & $7.70(0.60)$ & $8.50(0.40)$ \\
& & & & \\
\hline
\end{tabular}

- Average of 7 judges for each of the 6 trials. Figures in parentheses indicate standard deviations. 
near-globular shape in raw paneer. Verma (1989) observed a similar thread-like folded structure of both cow and buffalo milk rasogolla with finer and more uniformly distributed casein particles in cow milk rasogolla than that in buffalo milk rasogolla, similar to our observation. He also observed a more open texture and sponginess in cow milk than in buffalo milk rasogolla.

Texture, which is an important fundamental property of foods, arises from the size, shapes and micro- and macrostructural arrangements of the food particulates under differential processing conditions. Thus, a textural and structural study is essential in order to understand the physical and mechanical behaviour of foods during processing, storage and on consumption.

The greater hardness of buffalo milk rasogolla resulting from its denser, coarser protein matrix might be due to the casein micelle makeup and typical behaviour of buffalo milk during processing. It was observed that unlike cow casein, most of the caseins in buffalo milk are present in the micellar form (Sabarwal and Ganguli, 1971). The ratio of micellar to soluble casein for buffalo milk was found to be 91 as against 21 in cow milk. The authors also observed that buffalo milk casein micelles were larger in size than those in cow milk and also that the micellar organization in buffalo and cow milk was not identical (Ganguli and Anavkar, 1971). It was also found that as the buffalo milk casein micelles were larger in size, the aggregation of micelles was faster and their water retention capacity less during rennet coagulation as compared to cow casein micelles (Sabarwal and Ganguli, 1971). Thus, the heterogeneity in the structure of cow, buffalo and mixed milk rasogolla can be explained by the typical micellar behaviour of the buffalo milk caseins and the local difference in the $\mathrm{pH}$ values during the acid coagulation of milk (ie during chhana prep- aration) followed by severe physical changes during cooking (ie during rasogolla preparation).

Mixed milk rasogolla had lower hardness but higher crumbliness than that of buffalo milk rasogolla mostly due to the heterogenous nature of the protein matrix structure. This may be postulated as due to the differences in micellar organization, size and typical agglomeration characteristics of buffalo milk caseins as compared to those of cow milk caseins, which led to such an unhomogeneous micellar coalescence, with micelles thus retaining most of their separate identities.

The greater springiness of the buffalo milk product might be due to the differential casein micelle makeup and typical arrangement in the protein matrix to that of cow or mixed milk products. Better sugar syrup adsorption and more juiciness in cow milk rasogolla may be explained by the differences in pore size and shapes as evidenced from the light microscopic studies. The market sample had significant similarities to the structural and textural appearance of cow milk rasogolla, because the former is mostly manufactured from cow milk.

It is well established that the firmness of heat-induced milk gels is influenced by several physical and chemical factors presumably acting at the submicroscopic level. Electron microscopy was therefore used to search for an anticipated relationship between the texture and the ultrastructure of acid-coagulated followed by heat-processed milk product (rasogolla) as affected by varying concentrations of total solids, protein and other compositions. The higher concentration of milk solids accompanied by higher protein, fat and calcium contents, had a marked effect on the firmness of rasogolla as revealed by this study. The 1.83 -fold increase in hardness of buffalo milk rasogolla to that of cow milk rasogolla was due to the increase in total 
solids content of about $5 \%$ in buffalo milk rasogolla, whereas a slightly lower total solids content in mixed milk rasogolla also resulted in remarkable differences in the Instron textural values. The microstructural study showed that hardly any micelle retained its individuality in all the 3 types of rasogolla. Most of them were seen bound by fusion, forming chains or clusters with numerous voids in between, consequently giving different textural values. Kalab and Harwalkar (1974) also observed a close relationship between the ultrastructure and firmness of milk gels ranging widely in firmness. In gels containing 40 and $50 \%$ total solids (14 and $17 \%$ protein respectively), casein micelles appeared as individual entities, linked by some bridging materials but at $60 \%$ total solids ( $20 \%$ protein), the micelles were fused and offered a considerably higher resistance to the penetrometer probe. The following reasons may also be postulated for the greater hardness of buffalo milk rasogolla: i), the increased aggregation of casein particles with stronger links might have reduced the capacity of the fat and protein phases to move in relation to each other during compression by the Instron plunger; and ii), the protein matrix containing a smaller proportion of water reduced the mean free path of the casein micelles as compared to cow and mixed milk rasogolla, resulting in a higher degree of hardness in buffalo milk rasogolla.

\section{CONCLUSION}

The comparative scanning electron microscopic as well as light microscopic studies showed that buffalo milk rasogolla with a compact, ragged and scale-like structure was harder and chewier but less juicy and thus less acceptable than that of cow milk rasogolla which exhibited a loose protein matrix structure with numerous voids, thus resulting in better sensory textural ratings.
Excessive rupture of fat globules in buffalo milk rasogolla led to the release of a significant amount of free fat, which may adversely affect the shelf-life of the product during storage.

Thus this study revealed that by manipulating the casein micelle framework and altering the chemical composition of buffalo milk (ie by various process treatments or chemical modifications), or by using mixed milk, a better quality product could be produced with a similar textural and structural appearance to that of cow milk rasogolla, which may provide some alternatives to meeting the domestic as well as the export demand for rasogolla in India.

\section{ACKNOWLEDGMENTS}

The authors thank M Kalab (Agriculture Canada, Ontario, Canada) for his valuable suggestions on the SEM study and help in evaluating the photographs. The skilful technical help of KN Bagga and financial support of the National Dairy Research Institute (India) are also acknowledged.

\section{REFERENCES}

Association of Official Analytical Chemists (1975) Official Methods of Analysis of the $A O A C$. AOAC Washington DC 12th edn, 11

Association of Official Analytical Chemists (1984) Official Methods of Analysis of the AOAC. AOAC Arlington, VA, 14th edn, 281

Bhattacharya DC, Des Raj (1980) Studies on the production of rasogolla. Part I. Traditional method. Indian J Dairy Sci 33, 237-243

Birch GG, Mwangelwa OM (1974) Colorimetric determination of sugars in sweetened condensed milk products. J Sci Food Agric 25, 1355-1362

Brady PL, McKeith FK, Hunecke ME (1985) Comparison of sensory and instrumental texture profile techniques for the evaluation of beef and beef soy loaves. J Food Sci 50 , 1537-1540 
Creamer LK, Berry GP, Martheson AR (1978) The effect of $\mathrm{pH}$ on protein aggregation in heated skim milk. $N Z J$ Dairy Sci Technol 13, 9-15

Date WB, Lewis YS, Johar DS, Bhatia DS (1958) Studies on the preparation and preservation of rasogolla. Food Sci (India) 7, 217-223

Davies DT, White JCT (1962) The determination of calcium and magnesium in milk and milk diffusate. J Dairy Res 29, 285-298

Ganguli NC (1974) Physico-chemical make up of buffalo milk in the standardization of techniques of handling, processing and manufacturing of products. 19th Int Dairy Congr 1E, 358-376

Ganguli NC, Anavkar AS (1971) Micellar stability in relation to heat and the electrolyte system in cow and buffalo milk. Indian J Dairy Sci 24, 143-151

Heertje I, Visser J, Smits P (1985) Structure formation in acid milk gels. Food Microstruct 4, 267-277

Jagtiani JK, lyenger JR, Kapur NS (1960) Studies on the preparation and preservation of rasogolla. Food Sci (India) 9, 46-47

Kalab M, Harwalkar VR (1973) Milk gel structure. I. Application of scanning electron microscopy to milk and other food gels. J Dairy Sci $56,835-842$

Kalab M, Harwalkar VR (1974) Milk gel structure. II. Relation between firmness and ultra- structure of heat induced milk gels containing $40-60 \%$ total solids. J Dairy Res $41,131-135$

Kalab M, Gupta SK, Desai HK, Patil GR (1988) Development of microstructure of raw, fried and fried and cooked paneer made from buffalo, cow and mixed milks. Food Microstruct 7, 83-91

Lee C, Imoto EM, Rha C (1978) Evaluation of cheese texture. J Food Sci 43, 1600-1605

Mojonnier T, Tory HC (1925) The Technical Control of Dairy Products. Mojonnier Bros Co, Chicago, IL, 2nd edn, 936

Sabarwal PK, Ganguli NC (1971) Studies on the casein micelle of buffalo milk. Part III. Distribution pattern of micellar and soluble caseins as revealed by differential ultracentrifugation. Indian J Dairy Sci 24, 16-24

Soni K, Bandyopadhyay AK, Ganguli NC (1980) Manufacture of rasogolla from buffalo milk. Indian J Dairy Sci 33, 357-365

Szczesniak AS (1963) Classification of textural characteristics. J Food Sci 28, 385-398

Verma BB (1989) Technological studies on production of rasogolla from buffalo milk. $\mathrm{Ph} D$ Thesis, Kurukshetra University, Kurukshetra, India, 141-143

Zittle CA, Thompson HP, Custer JH, Cerbulis J (1962) $\kappa$-casein and $\beta$-lactoglobulin interaction in solution when heated. J Dairy Sci 45 , 807-810 